\title{
Corrosion Inhibition of Zinc Metal in Hydrochloric acid Solution by Using Ciprofloxacin Drug as an Inhibitor
}

\author{
Osama Bedran, Ali Al-Maamar, Dheaa Zageer and Emad Yousif \\ Department of Chemistry, College of Science, Al-Nahrain University, Baghdad-Iraq.
}

\begin{abstract}
The corrosion of zinc in $4 \mathrm{M} \mathrm{HCl}$ by has been investigated at room temperature, and at different temperatures using weight loss measurements, and inhibited by using ciprofloxacin drug. Results obtained showed that ciprofloxacin is a convenient inhibitor and its inhibition efficiency (IE \%) increased with the increase of inhibitor concentration. The best temperature which showed the lowest corrosion rate values was at $318 \mathrm{~K}$. The mechanism of adsorption had been explained on the basis of chemical structure of the investigated inhibitor. It was found that the protection of zinc metal using this corrosion inhibitor is not complicated at room temperature, and the optimum concentration of inhibitor has been calculated which had showed the maximum surface coverage.
\end{abstract}

Keywords: inhibition efficiency; Zinc metal; ciprofloxacin.

\section{Introduction}

Corrosioncan be defined as the degradation of a material when it comes in contact with the environment. The dissolving of a material by a corrosive liquid is called chemical corrosion [1]. The material continues to dissolve until either it is consumed or the liquid is saturated. A simple example is salt dissolving in water. The removing of metal atoms from a solid material as the result of an electric circuit is called electrochemical corrosion [2]. In this form of corrosion, metal atoms lose electrons and become ions thus forming a byproduct. Electrochemical corrosion occurs most frequently in aqueous mediums, in which ions are present in water or moist air. In this process, an electric circuit is created and the system is called an electrochemical cell. Corrosion of a steel pipe or a steel automobile panel, creating holes in the steel and rust as the byproduct, are examples of this reaction [3]. An inhibitor is a substance which when added in small quantities to a corrosive fluid decreases the corrosion rate by several orders of magnitude [6]. An inhibitor can be regarded as a retarding catalyst. They can be classified into several groups according to the mechanisms by which they function.

a. The Absorption Type get absorbed on the surface of the metal that corrodes and suppress the metal dislocation and reduction reactions. (ex. organic amines).

b. Scavengers are a special type of inhibitors which remove the corrosion causing reagents from the environment. (ex. sodium sulfite, hydrazine).

c. Vapor Phase Inhibitors are similar to the adsorption type and possess a high vapor pressure. They can be placed in the environment without any contact with the metal. They form a thin adsorbed layer on the metal by sublimation followed by condensation on the surface.

d. Oxidizers are the substances which are effectively used to inhibit the corrosion of metals that demonstrate active-passive transitions like iron, titanium etc. (ex. chromate, nitrate).

e. Hydrogen Evolution Inhibitors, such as antimony, retard the hydrogen reduction reaction $[7,8]$.

\section{Experimental Part}

Zinc strips of BDH grade were used in dimension $(8 \mathrm{~cm} * 2 \mathrm{~cm} * 0.5 \mathrm{~mm})$ (length, width, and thickness), and a solution of $4 \mathrm{M} \mathrm{HCl}$ was prepared. Ciprofloxacin inhibitor was prepared in $500 \mathrm{ppm}$ concentration, thereafter subsequent dilution was employed to prepare solutions 400,300,200, and 100ppm.Zinc strip was immersed in $\mathrm{HCl}$ solution in absence of inhibitor for specific periods of time and weighed in electronic balance after each period. Weight loss measurements [9]:For weight loss measurements, the following formulae were employed $[10,11]$ :

$$
\Delta \mathrm{m}=\left(\mathrm{m}_{1}-\mathrm{m}_{2}\right)
$$


Where $m_{1}$ and $m_{2}$ are the weights of metal before and after exposure to the corrosive solution, respectively. The percentage of inhibition efficiency (IE \%) and the degree of surface coverage $(\theta)$ of the investigated compounds was calculated from the following equations:

IE $\%=[1-(\Delta \mathrm{m}$ inh $/ \Delta \mathrm{m}$ free $)] \times 100$

$\theta=[1-(\Delta \mathrm{minh} / \Delta \mathrm{m}$ free $)]$

Where $\Delta \mathrm{m}$ free and $\Delta \mathrm{m}$ inh are the weight losses in the absence and presence of inhibitor, respectively.

\section{Results and Discussion}

The Table (1) shows the values of corrosion rate of zinc strips in $4 \mathrm{M} \mathrm{HCl}$ solution during specific periods, and the weight loss measurements were achieved, the weight of strips was decreasing, and the evolution of hydrogen gas was so obvious during the corrosion experiments, and the formation of zinc chloride as well.

Table (1)

The corrosion rate of zinc strip during specific periods at $298 \mathrm{~K}$.

\begin{tabular}{|c||c|}
\hline Time/minutes & $\begin{array}{c}\Delta \boldsymbol{m} / \Delta t \\
\text { (Corrosion rate) }\end{array}$ \\
\hline \hline 20 & 0.316 \\
\hline \hline 40 & 0.294 \\
\hline 60 & 0.214 \\
\hline 80 & 0.121 \\
\hline 100 & 0.04 \\
\hline 120 & 0.05 \\
\hline 140 & 0.055 \\
\hline 160 & 0.083 \\
\hline \hline 180 & 0.054 \\
\hline
\end{tabular}

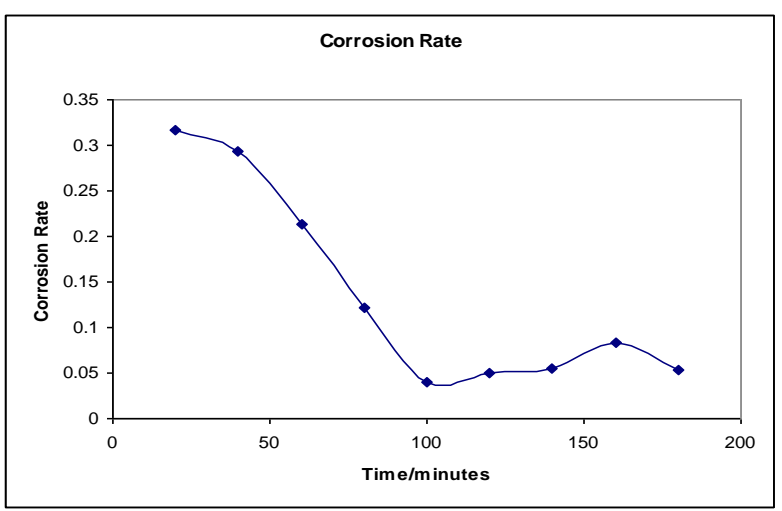

Fig.(1) The corrosion rate of zinc strip at $298 K$.

Fig.(1) showed that the corrosion is decreasing during the time, since the corrosion graph is descending to the lowest value of the corrosion rate. The introduction of ciprofloxacin as an inhibitor was via experiencing its own capability to be dispersed on the surface of the zinc strips, the chemical structure of ciprofloxacin is as follows:<smiles>O=C(O)c1cn(C2CC2)c2cc(N3CCNCC3)c(F)cc2c1=O</smiles>

\section{Fig. (2) The chemical structure of ciprofloxacin.}

According to its structure, the ciprofloxacin drug might be considered as an adsorption inhibitor according to the classification of inhibitors that formerly mentioned, so the adsorption was occurred on the surface of zinc strip, but it is necessary to know what is the optimum concentration.

Table (2)

The corrosion rates at different concentration of ciprofloxacin at $298 \mathrm{~K}$.

\begin{tabular}{|c||c||c||c||c|}
\hline $\begin{array}{c}\text { Timel } \\
\text { minutes }\end{array}$ & $\begin{array}{c}500 \\
\text { ppm }\end{array}$ & $\begin{array}{c}400 \\
\text { ppm }\end{array}$ & $\begin{array}{c}300 \\
\text { ppm }\end{array}$ & $\begin{array}{c}200 \\
\text { ppm }\end{array}$ \\
\hline \hline 20 & 0.017 & 0.018 & 0.01 & 0.717 \\
\hline \hline 40 & 0.015 & 0.014 & 0.105 & 0.674 \\
\hline \hline 60 & 0.02 & 0.022 & 0.023 & 0.015 \\
\hline \hline 80 & 0.016 & 0.021 & 0.014 & 0.017 \\
\hline \hline 100 & 0.021 & 0.021 & 0.025 & 0.02 \\
\hline
\end{tabular}


It could be inferred from Table (2) that the corrosion rates are descending during time, in comparison with table- 1 , the corrosion rate at 20 minutes was 0.316 , but in table- 2 the values are less than that number except in the concentration of $200 \mathrm{ppm}$, but it is optimum at 300 ppm.

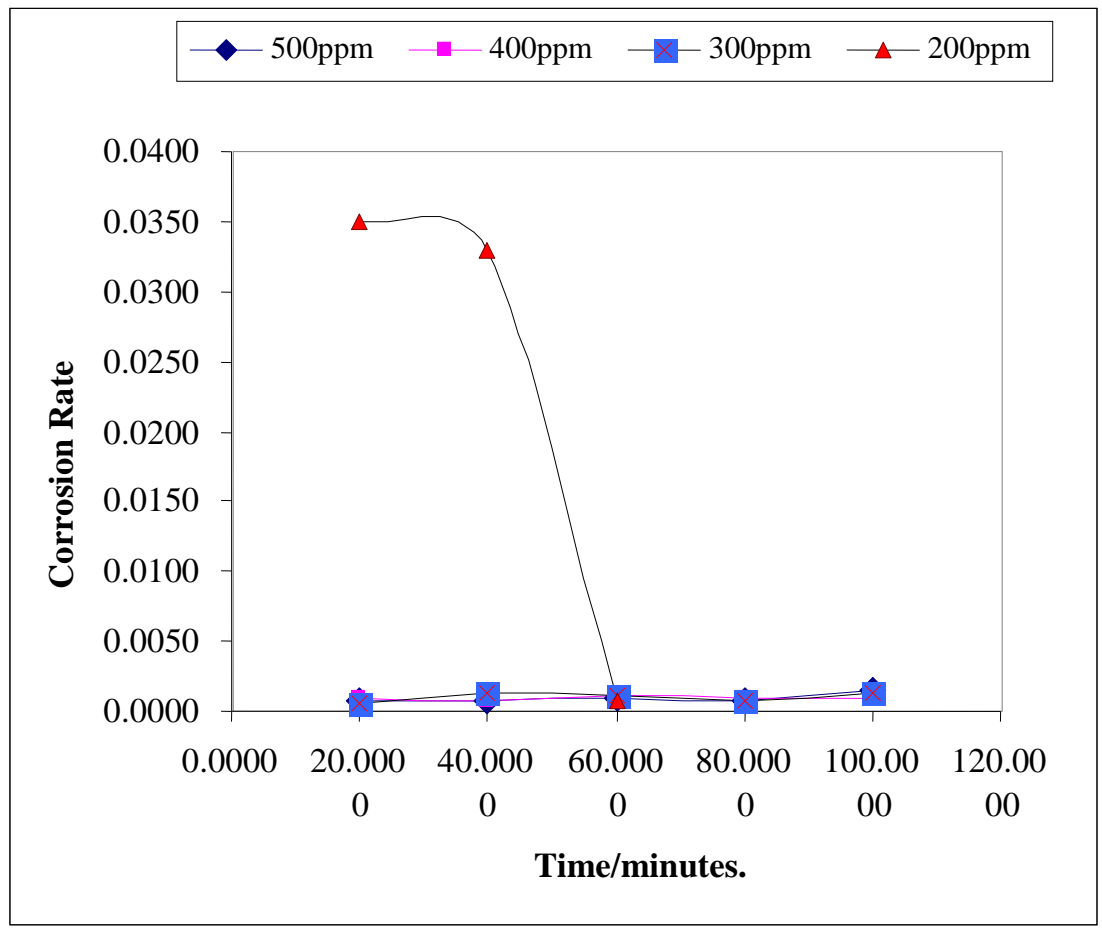

Fig. (3) The corrosion rate values in presence of ciprofloxacin drug at $298 \mathrm{~K}$.

Table (3)

The values of surface coverage ( $\theta)$ of ciprofloxacin at different concentrations at $298 \mathrm{~K}$.

\begin{tabular}{||c||c|c||c||c||c||}
\hline Concentration & $\mathbf{2 0}$ min. & $\mathbf{4 0}$ min. & $\mathbf{6 0}$ min. & $\mathbf{8 0}$ min. & $\mathbf{1 0 0}$ min. \\
\hline \hline $500 \mathrm{ppm}$ & 0.964 & 0.949 & 0.906 & 0.867 & 0.475 \\
\hline \hline $400 \mathrm{ppm}$ & 0.943 & 0.952 & 0.897 & 0.826 & 0.475 \\
\hline \hline $300 \mathrm{ppm}$ & 0.969 & 0.909 & 0.893 & 0.885 & 0.375 \\
\hline
\end{tabular}

Table (3) shows that the maximum surface coverage is at $300 \mathrm{ppm}$, and after 20 minutes of exposure to the ciprofloxacin drug, almost most of ciprofloxacin molecules have oriented themselves to be in a maximum attraction to the surface of zinc, so the adsorption would occur on the surface of zinc strip. The inhibition efficiency was calculated for all concentrations of ciprofloxacin drug and it was 96.9 for $300 \mathrm{ppm}$ concentration. 
Table (4)

The values of inhibition efficiency of ciprofloxacin drug at $298 \mathrm{~K}$.

\begin{tabular}{|c||c||c||c||c|c|}
\hline Concentration & $\begin{array}{c}20 \\
\text { min. }\end{array}$ & $\begin{array}{c}40 \\
\text { min. }\end{array}$ & $\begin{array}{l}60 \\
\text { min. }\end{array}$ & $\begin{array}{c}80 \\
\text { min. }\end{array}$ & $\begin{array}{c}100 \\
\text { min. }\end{array}$ \\
\hline \hline $500 \mathrm{ppm}$ & 96.4 & 94.9 & 90.6 & 86.7 & 47.5 \\
\hline \hline $400 \mathrm{ppm}$ & 94.3 & 95.2 & 89.7 & 82.6 & 47.5 \\
\hline $300 \mathrm{ppm}$ & 96.9 & 90.9 & 89.3 & 88.5 & 37.5 \\
\hline
\end{tabular}

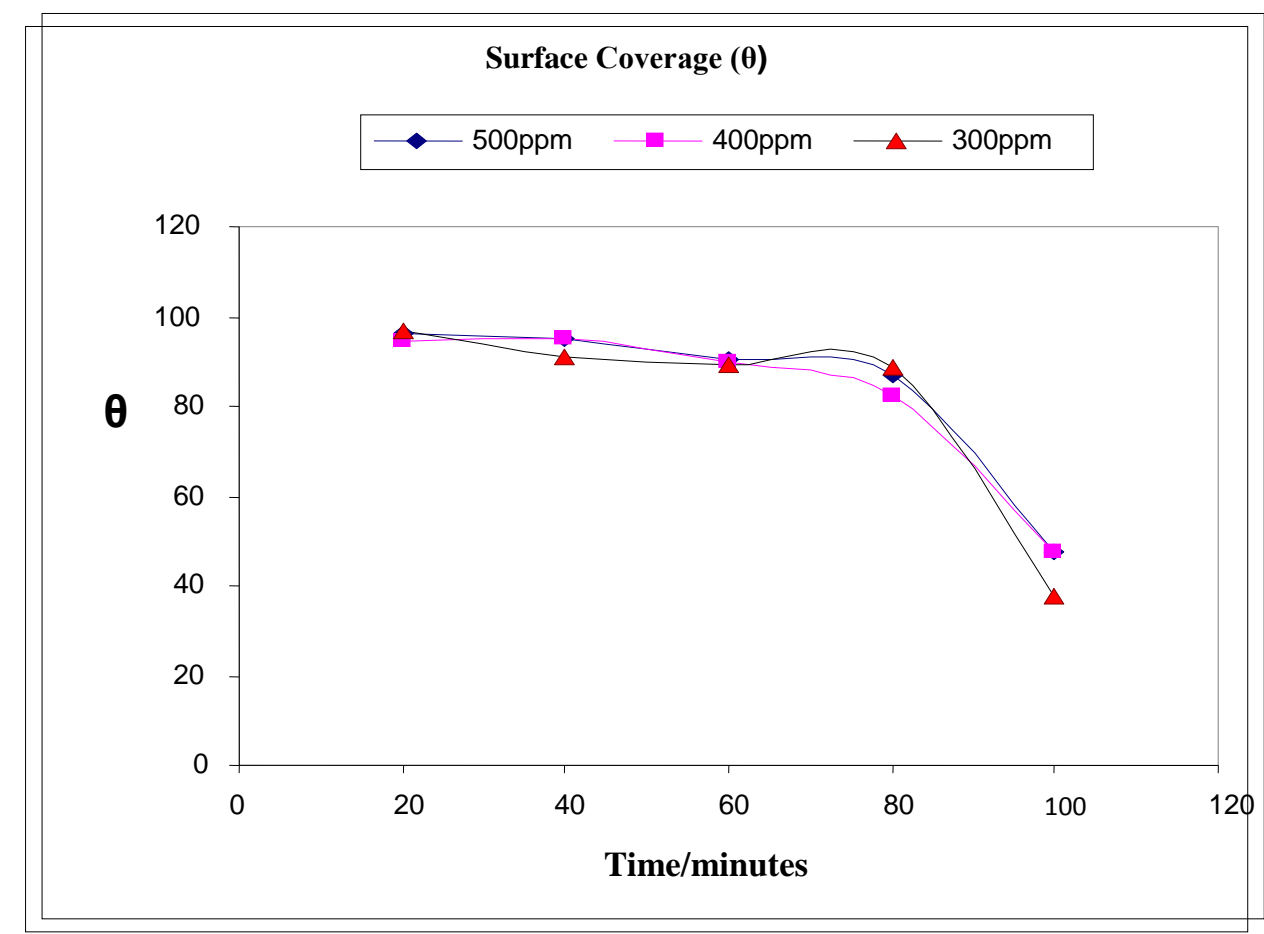

Fig. (4) The surface coverage at different concentrations of ciprofloxacin drug at $298 \mathrm{~K}$.

Table (5)

The corrosion rates at different temperatures.

\begin{tabular}{|c||c||c||c||}
\hline \multirow{2}{*}{ Time/minutes } & $\mathbf{3 0 8 K}$ & $\mathbf{3 1 8 K}$ & $\mathbf{3 2 8 K}$ \\
\cline { 2 - 4 } & $\boldsymbol{C R}$ & $\boldsymbol{C R}$ & $\boldsymbol{C R}$ \\
\hline \hline 20 & 0.211 & 0.162 & 0.0177 \\
\hline \hline 40 & 0.314 & 0.084 & 0.096 \\
\hline \hline 60 & 0.367 & 0.099 & 0.123 \\
\hline 80 & 0.425 & 0.121 & 0.201 \\
\hline \hline 100 & 0.229 & 0.0789 & 0.179 \\
\hline
\end{tabular}

Table (5) shows the corrosion rates of zinc at different temperatures, at $308 \mathrm{~K}$ the corrosion rate has been increased, and also it has been increased at $328 \mathrm{~K}$, but the values of corrosion rate at $318 \mathrm{~K}$ has been decreased. As shown in the Fig.(5), the rate of corrosion has been increased only at $308 \mathrm{~K}$, and $328 \mathrm{~K}$, but at
$318 \mathrm{~K}$ there was a slight decrement in the corrosion rate, referring to the Fig.(1), there was also a decrement in the corrosion rate of zinc. As shown in the Fig.(5), the rate of corrosion has been increased only at $308 \mathrm{~K}$, and $328 \mathrm{~K}$, but at $318 \mathrm{~K}$ there was a slight decrement in the corrosion rate, referring to the Fig.(1), there was also a decrement in the corrosion rate of zinc. 


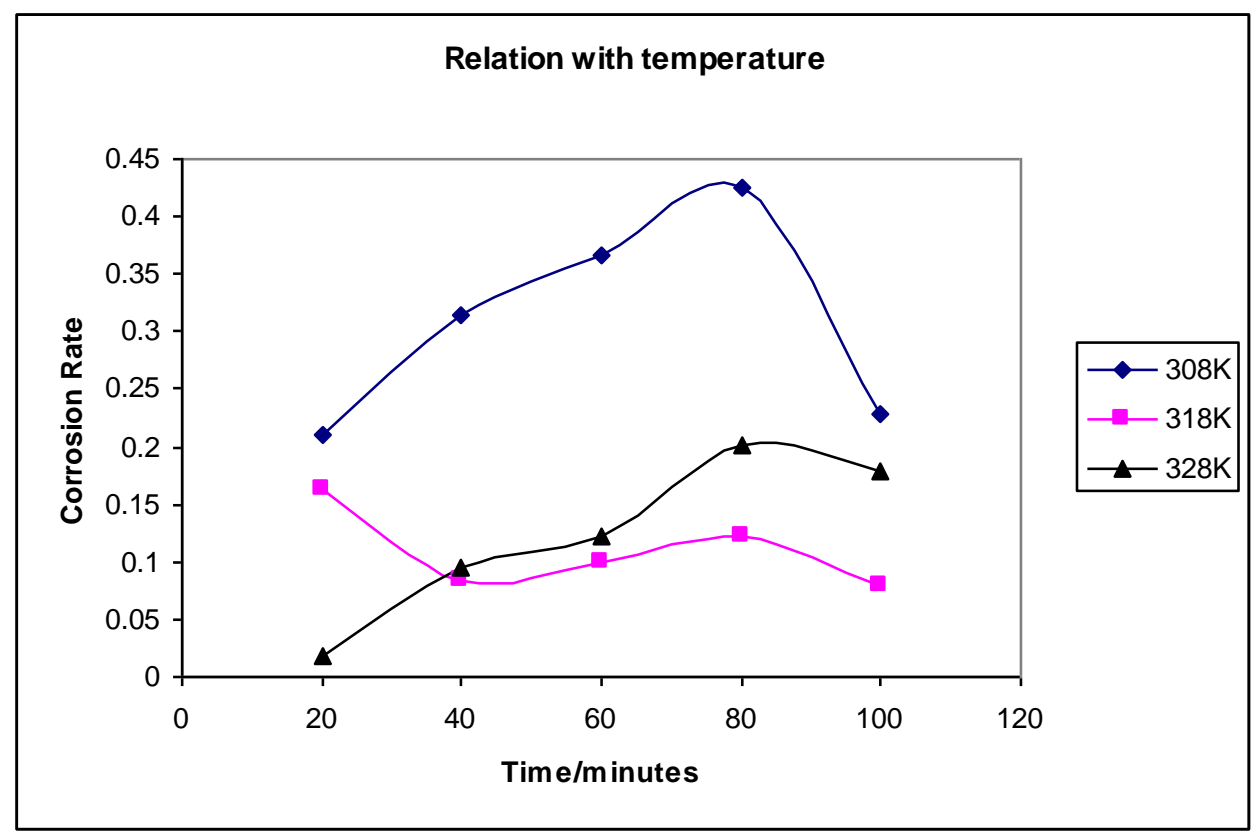

Fig.(5) The corrosion rate of zinc at different temperatures.

\section{Conclusion (s)}

In the light of the present study the following points have been concluded:

First, the zinc was stronger towards corrosion in presence of inhibitor (ciprofloxacin), and at $300 \mathrm{ppm}$. Second, the corrosion rate was decreased at $298 \mathrm{~K}$, and $318 \mathrm{~K}$, but it was increased at $308 \mathrm{~K}$, and $328 \mathrm{~K}$. Third, the surface coverage was high at $300 \mathrm{ppm}$ inhihibitor concentration which proves that the adsorption on the surface of zinc was optimum at this concentration, and the dispersal of ciprofloxacin molecules, penetration and coating was optimum as well.

\section{References}

[1].Shylesha B. S., Venkatesha T. V., Praveen B.M., Salicylideneaniline as inhibitor for the corrosion of mild steel in $1.0 \mathrm{~N}$, hydrochloric acid, J. Chem. Pharm. Res., 4(7), PP. 3414-3419, 2012.

[2].Odoemelam S. A., Ogoko E.C., Ita B. I., Eddy N. O., Inhibition of the Corrosion of Zinc in $\mathrm{H} 2 \mathrm{SO} 4$ by 9-deoxy-9a-aza-9amethyl-9a-homoerythromycin

(Azithromycin), Port. Electrochim. Acta, 27(1), PP. 57-68, 2009.

[3]. Shanbhag A. V., Venkatesha T V, Aprabhu R, Praveen B. M. , Inhibition effects of acetyl coumarines and thiazole derivatives on corrosion of zinc in acidic medium, Bull. Mater. Sci., 34(3), PP.571-576, 2011. [4].Shah M.D., Patel A.S., Mudaliar G.V., Shah N.K, Schiff Bases of Triethylenetetramine as Corrosion Inhibitorsof Zinc in Hydrochloric Acid, Portugaliae Electrochimica Acta, 29(2), PP. 101-113, 2011.

[5].Shah, M. D., Panchal, V.A.; Mudaliar, G.V.; Shah, N.K., Inhibitive effect of salicylidene-N-N'-dimorpholine towards corrosion of zinc in hydrochloric acid, Anti-Corrosion Methods and Materials, 58(3), PP. 125-130, 2011.

[6].Fouda A.S., Madkour L.H., El-Shafei A.A., Abd El-Maksoud S.A., corrosion inhibitors for zinc in $2 \mathrm{M}$ solution, Bull Korean Chem. Soc., 16(5), PP. 454-458, 1995.

[7]. Levie R. D., Advances in Electrochemistry and Electrochemical Engineering, vol 4, Interscience, New York 1967.

[8].Odoemelam S.A., Ogoko E.C., Ita B.I., Eddy N.O., Inhibition of the corrosion of zinc in $\mathrm{H}_{2} \mathrm{SO}_{4}$ by 9-deoxy-9-a-aza-9amethyl- 9a- homoerythromycin A, Portugaliae Electrochimica Acta, 27(1), PP. 57-68, 2009. 
[9].Singh A. K., Singh P.V., Synthesis, structural and corrosion inhibition studies on cobalt(II), nickel(II), copper(II) and zinc(II) complexes with 2-acetylthiophene benzoylhydrazone, Inorganica Chimica Acta, 379(15), PP. 56-63, 2011.

[10]. Zhang X.G., Corrosion and Electrochemistry of Zinc, Plenum Press, New-York, 1996.

[11]. Zhou H., Huang Q., Liang M., Lu D., Xu M., Li H., Investigation on synergism of composite additives forzinc corrosion inhibition in alkaline solution, Materials Chemistry and Physics, 128, PP. 214-21, 2011.

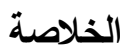

لقد نم دراسة نآكل معدن الخارصين في محلول ؛

مولاري حامض الهيدروكلوريك وفي درجات حرارية مختلفة باستخدام طريقة النقص في الوزن، وقد تم تثبيط تآكل الخارصين باستخدام دواء السبروفلوكساسين، وقد بينت

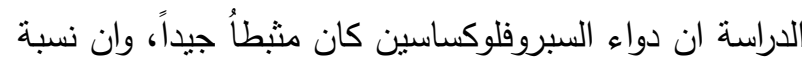
كفاءة التنثيط قد ازدادت بازدياد تركيز المنبط. لقد كانت درجة

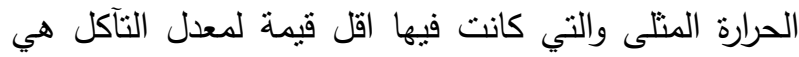
1اس كلفن. تم دراسة ميكانيكية الامتزاز على اساس التزكيب الكيميائي للمثبط، ولقد كانت حماية معدن الخارصين وامتزازه على سطح المعدن عملية غير معقدة ولقد كان نركيز الدواء الامتل هو . . r جزء من المليون والذي اظهر اكبر تغطية

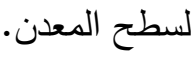

